Acta vet. scand. $1970,11,525-535$.

From the Department of Animal Husbandry and Genetics,

Veterinary College of Norway, Oslo.

\title{
SERUM ENZYME ACTIVITY \\ OF NEWBORN CALVES, PIGS, AND LAMBS
}

By

Sverre Tollersrud and Børge Baustad

Knowledge about the serum activity in newborn animals of enzymes which are being increasingly used as aids in clinical diagnostic work may be of practical importance in experiments of nutritional or hereditary character. A more theoretical question here is how far the activity of serum enzymes reflect metabolic changes in the early post-natal period.

Very few experiments on domestic animals seem to have been undertaken in this connection.

Madérová et al. (1963) found that calves were born with low serum activity of aspartate aminotransferase and alanine aminotransferase compared to the enzyme levels of normal maternal blood. They observed a very marked temporary increase in both enzymes shortly after birth, reaching a maximum at about 14 hrs. post partum. The elevation was interpreted to reflect high transferase activity found in colostrum consumed by the calves. In newborn pigs, Hyldgaard-Jensen (1968) reports elevated plasma values of total lactate dehydrogenase after colostrum feeding. The temporary increase shortly after birth, however, is explained as a consequence of the drastic metabolic changes taking place in the individual on transition from the intrauterine to the extrauterine life.

In the present paper serum levels of aspartate aminotrans- 
ferase $^{\star}$ ), alanine aminotransferase, and total lactate dehydrogenase in serum of calves, pigs, and lambs during the first two to three days of life are reported. Results from calves and pigs fed colostrum are compared with those from animals which did not receive any food for the first $24 \mathrm{hrs}$. Further, the $\mathrm{LDH}$ isoenzyme distribution in serum was determined in newborn pigs and lambs.

\section{MATERIAL AND METHODS}

\section{Animals}

Blood samples from 18 calves of the Norwegian Red Cattle breed were taken at intervals from birth to $72 \mathrm{hrs}$. of life.

All these calves were fed colostrum within six hrs. after birth.

Serum from four calves which did not receive colostrum or other feed for the first $24 \mathrm{hrs}$. was likewise analysed at frequent intervals during this time.

Nineteen newborn pigs from two litters of the Norwegian Landrace were bled at intervals during $48 \mathrm{hrs}$. The piglets were allowed to suck their dams. New blood samples were taken at the age of 13 days.

Five pigs of a third litter were deprived of colostrum for the first 24 hrs. During this time the pigs were given repeated intraperitoneal injections of $20 \mathrm{ml}$ of a $5 \%$ glucose solution.

Fourteen lambs of the native Norwegian short-tailed breed were investigated from birth to $72 \mathrm{hrs}$. of life. New blood samples were taken at an age of 10 days. All the lambs had access to colostrum.

In calves and lambs blood was drawn from the jugular vein, and in pigs from the anterior vena cava. Serum was obtained through immediate centrifugation for $10-15 \mathrm{~min}$. at 3,000 r.p.m. Sera from newborn animals with access to colostrum often showed an opaque colour, owing to a high lipid content. This was particularly seen in lambs. An additional centrifugation after a few hrs. of storing with removal of the upper lipid layer made the samples less turbid.

*) Nomenclature. Aspartate aminotransferase (EC 2.6.1.1), AspAT, previously named glutamate-oxalacetate-transaminase, GOT. Alanine aminotransferase (EC 2.6.1.2), AlAT, previously named glutamatepyruvate-transaminase, GPT. Lactate dehydrogenase (EC 1.1.1.27), $\mathrm{LDH}$. Isoenzymes: $\mathrm{LDH}_{1-5}$ with $\mathrm{LDH}_{1}$ as the most anodic fraction. 
As all animals were not bled at exactly the same points of time after birth, the values are recorded in time intervals as shown in the figures.

\section{Enzyme analyses}

Aspartate aminotransferase and alanine aminotransferase were determined according to the colorimetric method outlined in Sigma Technical Bulletin No. 505 (1964). The values are expressed as Sigma-Frankel (S-F) units. Total lactate dehydrogenase was determined according to the colorimetric method in Sigma Technical Bulletin No. 500 (1967), and the values expressed as Berger-Broida (B-B) units.

Electrophoretic separation of $\mathrm{LDH}$ isoenzymes in pig serum was performed as previously described by Baustad \& Tollersrud (1969). For sera of the other species the modifications reported by Tollersrud (1970) were applied.

\section{RESULTS}

\section{Calves}

Mean values of AspAT, AlAT, and total LDH in the serum of colostrum-fed calves during the first three days of life are given

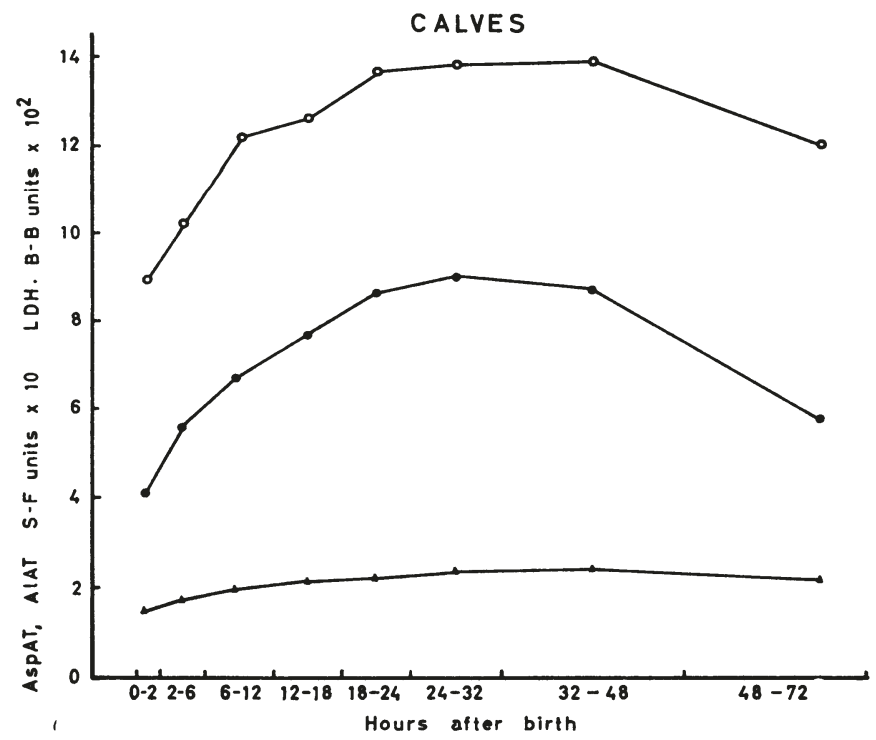

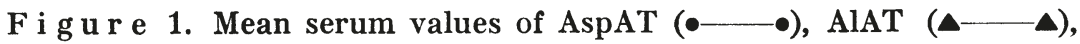
and total LDH (o- o) in calves from birth to $72 \mathrm{hrs}$. of life. 
in Fig. 1. The calves were born with a low serum activity of all the three enzymes investigated. In the course of one to two days after birth the values increased considerably, the transferases thus reaching the levels of normal maternal blood. During the next day a decline in the serum enzyme activity occurred to levels more commonly observed in young calves.

T a ble 1. Mean serum values of AspAT, AlAT, and total LDH in colostrum-deprived calves during $24 \mathrm{hrs}$. after birth.

\begin{tabular}{|c|c|c|c|c|c|c|}
\hline & Hrs.: & $0-2$ & $2-6$ & $6-12$ & $12-18$ & $18-24$ \\
\hline AspAT & & 33 & 53 & 57 & 65 & 86 \\
\hline AlAT & & 10 & 17 & 16 & 17 & 22 \\
\hline $\mathrm{LDH}$ & & 868 & 1040 & 1217 & 1425 & 1760 \\
\hline
\end{tabular}

Serum enzyme values of calves which did not receive colostrum are shown in Table 1.

A similar increase of serum activity obviously occurred in calves which were starved during the first day as in those fed colostrum. The increase of total LDH was even greater in starved animals.

The results strongly indicate that the temporary increase in serum activity shortly after birth is due to factors other than colostrum.

\section{Pigs}

Serum activity of AspAT, AlAT, and total LDH in newborn sucking pigs are given in Fig. 2.

A still more marked increase was observed in pigs than in calves during the first 24 hrs. After this time the activity of AspAT and LDH declined, whereas AlAT levels seemed to culminate at a later stage. After 13 days the activity had decreased to levels regarded as normal for young pigs, the AspAT value being at a rather low level.

Table 2. Mean serum values of AspAT, AlAT, and total LDH in colostrum-deprived pigs during $24 \mathrm{hrs}$. after birth.

\begin{tabular}{|c|c|c|c|c|c|c|}
\hline & Hrs.: & $0-2$ & $2-6$ & $6-12$ & $12-18$ & 18-24 \\
\hline AspAT & & 20 & 67 & 78 & 80 & 99 \\
\hline AlAT & & 12 & 24 & 36 & 34 & 44 \\
\hline J.DH & & 525 & 841 & 1123 & 992 & 1109 \\
\hline
\end{tabular}




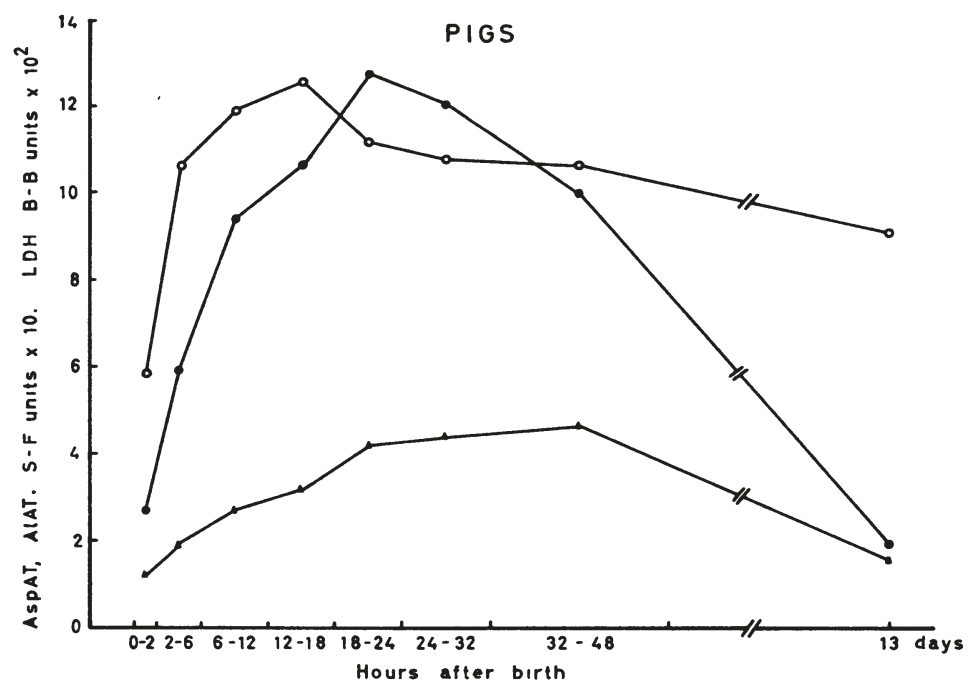

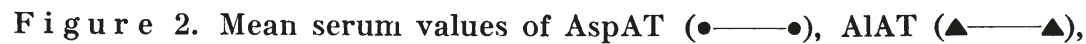
and total $\mathrm{LDH}(\mathrm{o}-\mathrm{o})$ in pigs from birth to $48 \mathrm{hrs}$. and at 13 days.

The serum enzyme changes in newborn pigs which did not receive colostrum are presented in Table 2.

Increasing activities of all three enzymes during the first day, independent of colostrum feeding, were thus also clearly demonstrated in pigs.

LDH isoenzymes. $\mathrm{LDH}$ isoenzymes in serum from colostrumfed pigs are presented in Table $3 . \mathrm{n}=$ number of samples within the respective time intervals.

Table 3. Mean percentage values $\pm s$ of $\mathrm{LDH}$ isoenzymes in serum of newborn pigs.

\begin{tabular}{lcccccr}
\hline Age in hrs. & $\mathrm{LDH}_{1}$ & $\mathrm{LDH}_{2}$ & $\mathrm{LDH}_{3}$ & $\mathrm{LDH}_{4}$ & $\mathrm{LDH}_{3}$ & $\mathrm{n}$ \\
\hline $0-2$ & $34.3 \pm 7.8$ & $19.1 \pm 3.5$ & $26.4 \pm 5.2$ & $18.5 \pm 4.8$ & $1.7 \pm 1.7$ & 15 \\
$2-6$ & $21.6 \pm 3.8$ & $17.1 \pm 1.0$ & $29.9 \pm 1.5$ & $27.4 \pm 6.7$ & $4.0 \pm 3.5$ & 5 \\
$6-12$ & $23.6 \pm 3.0$ & $17.2 \pm 1.1$ & $28.4 \pm 2.6$ & $25.0 \pm 4.9$ & $5.8 \pm 3.6$ & 17 \\
$12-18$ & $23.0 \pm 2.9$ & $19.3 \pm 3.7$ & $28.3 \pm 1.7$ & $22.2 \pm 3.2$ & $7.2 \pm 2.5$ & 14 \\
$18-24$ & $24.5 \pm 2.4$ & $21.1 \pm 1.6$ & $29.0 \pm 2.6$ & $20.8 \pm 3.4$ & $4.6 \pm 2.0$ & 13 \\
$24-32$ & $23.4 \pm 4.5$ & $23.8 \pm 2.8$ & $33.1 \pm 7.0$ & $17.3 \pm 0.5$ & $2.4 \pm 0.9$ & 3 \\
$32-48$ & $30.5 \pm 2.0$ & $25.7 \pm 2.1$ & $29.5 \pm 1.0$ & $12.4 \pm 3.0$ & $1.9 \pm 0.9$ & 10 \\
13 days & $37.1 \pm 8.9$ & $23.8 \pm 3.7$ & $25.7 \pm 6.4$ & $11.5 \pm 4.7$ & $1.9 \pm 2.1$ & 15 \\
\hline
\end{tabular}

The percentage distribution of $\mathrm{LDH}$ isoenzymes during the first two days of life did not change to the same extent as did 
total LDH. At 13 days, a change towards an isoenzyme pattern with higher anodic and lower cathodic fractions, as earlier reported for older pigs, seems to have occurred.

Since total $\mathrm{LDH}$ showed a very marked increase during the first $24 \mathrm{hrs}$, and the percentage isoenzyme distribution was kept on a steadier level, a calculated LDH activity of all five fractions showed increased values during the first day of life.

\section{Lambs}

Mean serum enzyme levels of AspAT, AlAT, and total LDH during the first three days are shown in Fig. 3.

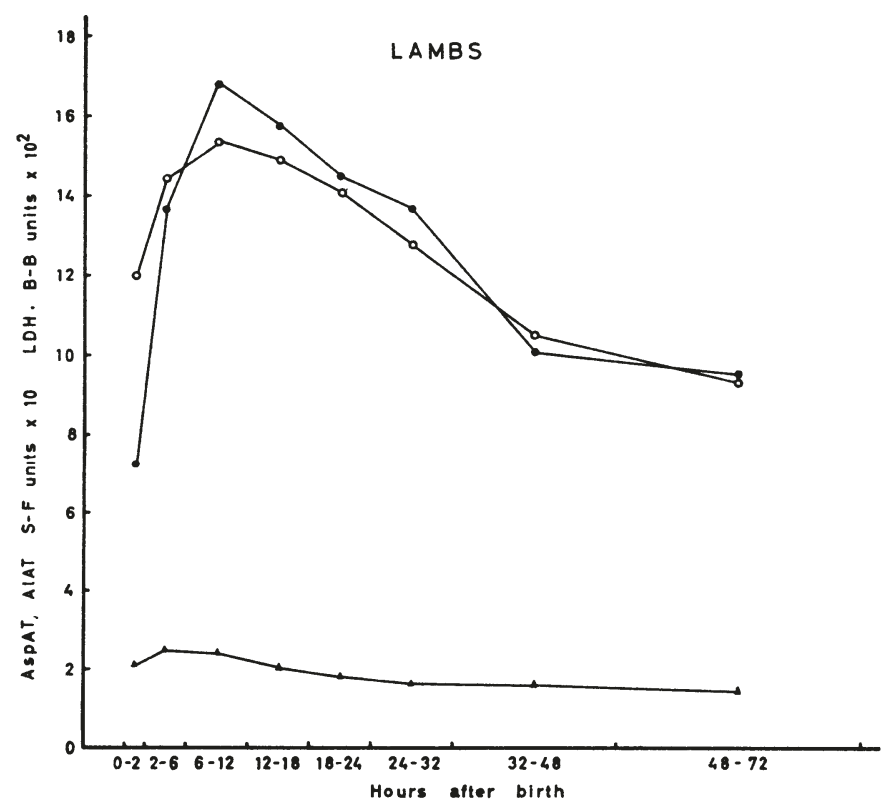

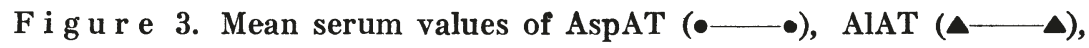
and total LDH (o-o) in lambs from birth to $72 \mathrm{hrs}$. of life.

Unlike calves and pigs, lambs seem to be born with relatively high levels of all three enzymes, compared to normal values of maternal blood. As observed in the two other species an increase in enzyme activity occurred during the first day. The mean peak values in lambs were recorded six to $12 \mathrm{hrs}$. after birth.

LDH isoenzymes. $\mathrm{LDH}$ isoenzymes in serum of lambs are presented in Table 4. 
T a b l e 4. Mean percentage values $\pm s$ of $\mathrm{LDH}$ isoenzymes in serum of newborn lambs.

\begin{tabular}{lcccccr}
\hline Age in hrs. & $\mathrm{LDH}_{1}$ & $\mathrm{LDH}_{2}$ & $\mathrm{LDH}_{3}$ & $\mathrm{LDH}_{4}$ & $\mathrm{LDH}_{5}$ & $\mathrm{n}$ \\
\hline $0-2$ & $25.5 \pm 1.8$ & $14.0 \pm 2.6$ & $40.8 \pm 6.0$ & $19.7 \pm 4.5$ & 0 & 5 \\
$2-6$ & $25.2 \pm 1.9$ & $15.3 \pm 0.9$ & $36.0 \pm 4.3$ & $23.5 \pm 5.8$ & 0 & 4 \\
$6-12$ & $23.1 \pm 4.3$ & $12.9 \pm 0.9$ & $41.1 \pm 7.8$ & $23.0 \pm 8.3$ & 0 & 6 \\
$12-18$ & $24.3 \pm 3.0$ & $14.9 \pm 0.4$ & $33.7 \pm 1.9$ & $27.1 \pm 1.5$ & 0 & 3 \\
$18-24$ & $\mathbf{2 7 . 3} \pm 2.4$ & $13.2 \pm 2.0$ & $36.6 \pm 3.3$ & $22.9 \pm 4.4$ & 0 & 6 \\
$\mathbf{2 4 - 3 2}$ & $\mathbf{2 9 . 0} \pm 1.5$ & $14.1 \pm 2.2$ & $36.4 \pm 1.7$ & $\mathbf{2 0 . 5} \pm 2.9$ & 0 & 6 \\
$\mathbf{3 2 - 4 8}$ & $30.7 \pm 3.0$ & $14.8 \pm 1.6$ & $34.5 \pm 1.8$ & $20.0 \pm 4.8$ & 0 & 6 \\
$48-72$ & $31.3 \pm 4.6$ & $14.9 \pm 1.2$ & $34.4 \pm 4.9$ & $19.4 \pm 2.5$ & 0 & 4 \\
10 days & $\mathbf{2 9 . 5} \pm 3.5$ & $16.6 \pm 1.9$ & $35.8 \pm 2.3$ & $18.1 \pm 5.7$ & 0 & 10 \\
\hline
\end{tabular}

The LDH isoenzyme distribution in the serum of lambs showed rather small changes from birth to 10 days. No distinct tendency towards the isoenzyme pattern found in adult sheep, characterized by higher $\mathrm{LDH}_{1}$ and a lower percentage of the other isoenzymes, could be seen at this time.

\section{DISCUSSION}

The results confirm the findings of Maderová et al. (1963) that calves are born with a low serum activity of the two transferases, and that a temporary increase occurs during the first day. The same phenomenon was observed in the present experiment of newborn pigs, and included also serum activity of total lactate dehydrogenase in the two species. Maderová et al. explained the enzyme elevation as a reflection of high transferase levels found in the colostrum consumed by the calves. The present results, however, showed a similar rise of serum enzyme activity in calves and pigs which were not given colostrum or other food for the first $24 \mathrm{hrs}$.

In contrast to the present findings in calves and pigs, which showed that these animals at birth had only about half the aspartate aminotransferase serum level of their dams, human infants are born with twice the activity of pregnant women (Glendening et al. 1955). An explanation of this difference may partly be sought in the placental structure. Animals as cattle and swine have a stronger placental barrier than human beings and will probably not permit passage of the enzyme molecules to the foetal blood. The molecular weight of the enzymes studied is about $120-130,000$. 
The main cause of increased serum enzyme activity is generally a necrosis of tissue with release of the cellular enzymes to the blood. In newborn, normal animals injury in the usual sense would seem to play no decisive part. However, marked elevations in serum enzyme levels may occur even in the abscence of any readily demonstrable histologic changes. The permeability of cell membranes is considered not to be fixed, but may be subject to metabolic control and can be varied physiologically.

Great changes are taking place in the metabolic activity of newborn animals. Hormonal regulation plays an important part in the intermediate metabolism, even if the mechanisms are not yet fully known (Velle 1964). Hormones such as ACTH, cortisone, insulin, and catecholamines are also found to increase the cellular membrane permeability and serum enzyme levels (Hess 1963). The temporary serum enzyme elevation observed in connection with stress and physical exercise in man and animals is assumed, at least partly, to be due to hormonal effects. The transfer from the uterine to the extrauterine life involving colder environments, increased physical activity, and a rapid growth might also be regarded as stressing factors to the newborn animal. That physical exercise may cause enhanced serum enzyme levels in young lambs is found in this department (Tollersrud et al. 1971).

Physiological changes, as mobilization of body fat, is known to occur in the early post-natal period. A significant increase of plasma free fatty acids is found in different animal species during the first $24 \mathrm{hrs}$. both in fed and starved individuals (Bengtson et al. 1969). Adipose tissue of man is very rich in the enzymes concerned (Hess).

A post-foetal destruction of red blood cells, rich in enzymes, could be a possible factor to increased serum activity. However, the LDH isoenzyme pattern of erythrocytes is greatly dominated by the anodic fractions.

In pigs and lambs great changes occurred in total serum lactate dehydrogenase shortly after birth, whereas the isoenzyme pattern proved to be more stable. These findings are in accordance with those of Hyldgaard-Jensen (1968) in his study of age depending changes of LDH in pigs. The present isoenzyme pattern of newborn pigs, however, showed a lower fraction of $\mathrm{LDH}_{1}$ and a higher percentage of $\mathrm{LDH}_{3}$ than previously observed in adult pigs (Baustad \& Tollersrud 1969). A similar trend was 
found in the isoenzyme distribution of newborn lambs compared with previous results of adult sheep (Tollersrud 1970).

According to Hyldgaard-Jensen an adult LDH isoenzyme pattern in pigs is obtained after five to eight weeks. A similar progress is reported in man (Gautier et al. 1962). Experiments in this department have shown that calves and lambs achieve an adult isoenzyme pattern at a somewhat later stage. Thus, serum of calves at an age of three and a half months showed a markedly lower $\mathrm{LDH}_{1}$ activity than found in adult cattle (Tollersrud). A significantly lower $\mathrm{LDH}_{1}$ fraction has also been observed in lambs at an age of two and a half months than in adult ewes (Tollersrud et al.).

During the first 24 hrs. after birth serum from pigs showed elevated values of $\mathrm{LDH}_{4}$ and $\mathrm{LDH}_{5}$. Relatively high proportions of these cathodic fractions have also been observed in serum of infants (Kreutzer \& Fennis 1964). A possible explanation of the cathodic isoenzyme elevation in newborns has been reported to be the relatively high contents of these fractions in placenta.

The present investigations demonstrate that widely different results in serum enzyme activity must be expected in newborn animals depending on the time of blood sampling during the first two to three days after birth. The $\mathrm{LDH}$ isoenzyme distribution, though fairly constant during this time, will show a pattern different from what is regarded as normal in adult animals of the respective species.

\section{REFERENCES}

Baustad, B. \& S. Tollersrud: Isoenzymes of lactate dehydrogenase in swine. Stability during storage at different temperatures and by heat treatment. Acta vet. scand. 1969, 10, 372-381.

Bengtson, G., J. Gentz, J. Hakkarainen, R. Hellstr $\phi m$ \& B. Persson: Plasma levels of FFA, glycerol, $\beta$-hydroxybutyrate and blood glucose during the postnatal development of the pig. J. Nutr. 1969, 97, 311-315.

Gautier, E., R. Gautier \& R. Richerich: Valeur diagnostique d'anomalies d'activitiés enzymatiques du sérum en pédiatrie. (The diagnostic value of serum enzyme activities in pediatric diseases). Helv. paediat. Acta 1962, 17, 415.

Glendening, M. B., A. M. Cohen \& E. W. Pace: Influence of pyridoxine on transaminase activity of human placenta, maternal and fetal blood. Proc. Soc. exp. Biol. (N.Y.) 1955, 90, 25-28. 
Hess, B.: Enzymes in Blood Plasma. Academic Press. New York and London 1963.

Hyldgaard-Jensen, J.: Mælkesyredehydrogenase hos svin. (Lactic dehydrogenase in pigs). Kgl. Vet.- og Landbohøjsk., Inst. Sterilitetsforskn. Aarsberetn. 1968, 243-284. København.

Kreutzer, H. H. \& W. H. Fennis: Lactic dehydrogenase isoenzymes in blood serum after storage at different temperatures. Clin. chim. Acta 1964, 9, 64-68.

Maděrová, V., V. Neuman \& F. Kozumplik: Development of serum transaminase activity in very young calves. Sborn. Výž. Sk. Zemeldelsk. Brno. Serb. 1963, 11, 187-188.

Tollersrud, S.: Heat stability of serum lactate dehydrogenase and its isoenzymes in young and adult cattle and sheep. Evaluation of a relative heat stability test and serum determination of $\alpha$-hydroxybutyrate dehydrogenase in diagnostic work. Acta vet. scand. $1970,11,510-524$.

Tollersrud, S., B. Baustad \& K. Flatlandsmo: Effects of physical stress on serum enzymies and other blood constituents in sheep. Acta vet. scand. 1971, 12. In press.

Velle, W.: Biosyntesen av fruktose i relasjon til endokrine reguleringsmekanismer. (The biosynthesis of fructosis in relation to hormonal mechanisms of regulations). Nord. Vet.-Med. 1964, 16, $1013-1028$.

\section{SUMMARY}

Serum activities of aspartate aminotransferase (AspAT $=$ GOT), alanine aminotransferase $(\mathrm{AlAT}=\mathrm{GPT})$, and total lactate dehydrogenase $(\mathrm{LDH})$ have been investigated in newborn calves, pigs, and lambs. In the two latter species the LDH isoenzyme distribution in serum was also studied. Blood samples were taken at frequent intervals from birth to $48-72 \mathrm{hrs}$. post partum.

Calves and pigs were born with very low serum enzyme values, whereas lambs showed a picture more similar to what has been reported in human infants. In all species a marked temporary enzyme increase occurred during the first 24-48 hrs. This elevation was found not to be due to colostrum feeding, since a parallel increase was found in starved animals. Possible regulating mechanisms are discussed.

The LDH isoenzyme pattern proved to be more stable than total LDH in the early post-natal period.

The percentage isoenzyme distribution, however, showed characteristic differences from that found in adult animals of the same species. 


\section{SAMMENDRAG}

Serumenzymaktivitet hos nyfødte kalver, griser og lam.

Enzymaktiviteten i serum av aspartataminotransferase (AspAT = GOT), alaninaminotransferase (AlAT $=$ GPT) og laktatdehydrogenase (LDH) er unders $\varnothing \mathrm{kt}$ hos nyf $\varnothing$ dte kalver, griser og lam. Hos de to siste artene ble også de forskjellige fraksjoner eller isoenzymer av LDH unders $\varnothing$ kt. Blodpr $\varnothing$ ver ble tatt av de nyf $\varnothing$ dte dyrene med korte mellomrom i to-tre d $\phi \mathrm{gn}$ etter fødselen.

Kalver og griser ble f $\phi \mathrm{dt}$ med lave enzymverdier, mens lam viste et bilde som ligner mer på det som er beskrevet for nyfødte barn. Hos alle dyrearter skjedde det en meget kraftig temporær stigning av enzymaktiviteten i løpet av ett eller to døgn. Denne stigning må ha andre årsaker enn fóring med råmelk, da dyr som ble sultet de f $\varnothing$ rste 24 timer, viste en lignende enzym $\varnothing$ kning. Mulige reguleringsmekanismer er diskutert.

Isoenzymm $\varnothing$ nsteret av $L D H$ viste seg å være mer stabilt $i$ den f $\varnothing$ rste tiden etter f $\varnothing \mathrm{dsel}$ enn total LDH. Den prosentvise fordelingen av isoenzymene viste imidlertid karakteristiske ulikheter fra det en finner hos voksne individer innen samme dyreart.

(Received February 2, 1970). 